\title{
PERAN MOTIVASI KERJA DAN DUKUNGAN SUAMI TERHADAP STRES KONFLIK PERAN GANDA DAN KEPUASAN PERKAWINAN
}

\author{
Eva Meizara Puspita Dewi \& Abdul Saman \\ Universitas Negeri Makassar, Jl. Raya Pendidikan No. 1 Makassar \\ email: absan_unm@yahoo.co.id
}

\begin{abstract}
Abstrak
Tujuan penelitian ini adalah untuk menganalisis (1) dampak motivasi kerja stress konflik yang disebabkan oleh peran ganda wanita karir, (2) efek dukungan suami istri terhadap stress konflik yang disebabkan oleh peran ganda wanita karier, (3) pengaruh dukungan suami istri terhadap kepuasan pernikahan wanita karier, dan (4) Pengaruh stress konflik peran ganda pada wanita karier dan kepuasan pernikahan mereka. Penelitian ini menggunakan pendekatan kualitatif. Ada 30 karyawan BNI cabang Makasar diambil sebagai subjek berdasarkan metode purposive sampling 4 skala alat penelitian diaplikasikan dengan menggunakan program SPSS windows 14 yang digunakan untuk menganalisis data. Hasil penelitian menunjukkan (1) adanya dampak negative motivasi kerja mengenai stress konflik peran ganda pada wanita karier $(r=0.436),(2)$ adanya dampak negative dukungan suami istri mengenai stress konflik yang disebabkan oleh peran ganda wanita karier $(r=0.475)$, (3) adanya pengaruh positif mengenai dukungan suami istri terhadap kepuasan pernikahan wanita karier $(r=0.645)$, dan (4) adanya pengaruh negative terhadap stress konflik peran ganda wanita karier dan kepuasan pernikahan mereka $(r=0.429)$
\end{abstract}

Kata kunci: motivasi kerja, dukungan suami istri, stress konflik peran ganda, kepuasan pernikahan dan wanita karier.

\section{Abstract}

The purpose of this research was to analize (1) the impact of work motivation to conflict stress caused by doble roles on career women, (2) the effect of spouse support to conflict stress caused by doble roles on career women, (3) the influence of spouse support to marriage contentment on career women, and (4) The influence of conflict stress of doble roles on career women and their marriage contement. This research employed quantitatif approch. There were 30 employees of BNI Makassar branch taken as subjects based on purposive sampling method. The 4 scale research instrument was applied while regression program of SPSS windows 14.00 was employed to analize the data. Study found that (1) there were negative impact of work motivation to conflict stress of doble roles on career women $(r=0,436)$, (2) there were negatif effect of spouse support to conflict stress caused by doble roles on career women $(r=0,745)$, (3) there were positif influence of spouse support to marriage contentment on career women $(r=0,645)$, and (4) there were negative influence of conflict stress of doble roles on career women and their marriage contement $(r=0,429)$.

Keywords: work motivation, spouse support, stress conflict of double roles, marriage contentment, career women 


\section{PENDAHULUAN}

Wanita bekerja bukanlah merupakan hal yang baru. Mangunwijaya (Setyowati \& Riyono, 2003) menyatakan bahwa peran wanita tak pernah bisa diabaikan, walaupun pada bidangbidang tertentu wanita tidak atau belum diizinkan memegang peranan langsung, secara operasional justru wanita yang menjadi penggerak. Kenyataan yang bisa kita lihat sekarang adalah semakin meluasnya peluang dan kesempatan wanita untuk tampil kedepan.

Wanita bekerja umumnya dengan alasan mencari uang tambahan atau membantu suami dalam mencari nafkah, akan tetapi tujuan dan motivasi wanita modern dalam bekerja telah berbeda, selain untuk mencari uang, tujuan lainnya adalah juga untuk mencari eksistensi diri. Horner (Prabandari, 2003) menjelaskan bahwa ada perbedaan yang mendasar antara dua jenis kelamin dalam orientasinya terhadap bekerja. Perbedaan orientasi pria dan wanita adalah bahwa pria lebih berorientasi pada kesuksesan berafiliasi. Sedangkan menurut Hoffman (Prabandari, 2003) mengemukakan bahwa wanita lebih termotivasi untuk berafiliasi daripada untuk meraih prestasi.

Dilema wanita bekerja timbul karena adanya peranan dan fungsi sebagai wanita. Dilema ini dialami pada wanita sedangkan pada pria tidak, karena menurut Panca Dharma Wanita Indonesia menuntut seorang wanita dapat melakukan lima tugas, yaitu sebagai istri atau pendamping suami, sebagai pengelola rumah tangga, sebagai penerus keturunan, sebagai ibu dari anak-anak, dan sebagai warga negara. Dengan keadaan ini, memang berat peranan sebagai seorang wanita. Hal ini tidak mungkin semuanya berjalan dan sulit untuk mencapai hasil yang maksimal (Anoraga, 2005).

Bagi wanita bekerja yang juga sekaligus istri, dan ibu rumah tangga sulit lepas begitu saja dari lingkungan keluarganya, sehingga dapat dikatakan bahwa dalam meniti karir seorang wanita mempunyai beban dan hambatan yang lebih berat bila dibandingkan dengan kaum pria. Oleh sebab itu, jika wanita tidak pandai-pandai untuk menyeimbangkan peranperan mereka, maka pada akhirnya akan menimbulkan konflik peran pada diri wanita tersebut. Konflik peran ganda yang dialami oleh setiap perempuan berbeda. Hal ini juga dikemukakan dalam penelitian yang dilakukan oleh Himam \& Putri (2005), bahwa ibu yang bekerja (berkarir) mengalami dilema. Penyebab dan dampak pada setiap orang tidak ada yang sama persis.

Wanita karir yang memiliki motivasi kerja kebutuhan aktualisasi diri ini dapat mengalami konflik peran ganda karena disatu sisi dia ingin menjadi ibu rumah tangga dan disisi lain dia juga ingin bekerja untuk memenuhi kebutuhan aktualisasi dirinya. Hal ini juga sependapat dengan penelitian tentang wanita yang bekerja. Penelitian ini dilakukan oleh Monty \& Henny (Suryadi, 2003) yang menemukan bahwa subjek mengalami konflik antar peran ketika menjalani peran ganda. Konflik juga muncul karena adanya kebutuhan untuk memiliki dan cinta dengan kebutuhan akan aktualisasi diri. Reaksi emosional yang mereka rasakan berupa kesedihan, kebingungan, kemarahan, dan keharuan.

Banyaknya peran yang harus dijalani oleh wanita bekerja memunculkan kemungkinan kekurangan waktu dan energi untuk membina hubungan perkawinan mereka. Bila istri memutuskan untuk bekerja diluar rumah berarti mereka mengurangi kualitas perannya dalam perkawinan dan mengurangi waktu bersama pasangannya yang pada akhirnya berpengaruh terhadap kualitas perkawinan. Ditambah lagi dengan sebagian wanita yang bekerja tidak mampu lagi untuk memenuhi peran tradisionalnya sebagai seorang istri. Hal ini berpotensi timbulnya ketegangan atau konflik dalam perkawinan.

Penelitian yang dilakukan oleh Geerken dan Give (Rini, 2002) menemukan bahwa pada tahap awal perkawinan sebelum mempunyai anak hubungan perkawinan akan lebih baik bila istri bekerja daripada istri tidak bekerja. Namun setelah mempunyai anak pasangan dimana istri tidak bekerja akan memiliki kepuasan perkawinan yang lebih baik daripada istri yang bekerja. Ini berarti, keterlibatan dalam sektor publik atau bekerja dikantor dapat berpotensi menimbulkan konflik peran. Wanita bekerja dihadapkan pada tuntutan yang samasama penting antara tugas di kantor dengan tugasnya dalam keluarga.

Berdasarkan penelitian mengenai stres yang dihadapi pada wanita berperan ganda, maka dukungan dari pasangan (suami) tentunya sangat berarti. Apabila istri tidak mendapatkan dukungan dari suami maka istri tidak dapat menikmati peran dalam dunia kerja, merasa tidak optimal dalam menjalankan peran 
sebagai istri sehingga mengalami stres. Menurut Suriyasan (Tenriawaru, 2005) faktor penting yang dapat mengurangi dilema antara keluarga dan pekerjaan bagi wanita yang berperan ganda adalah adanya dukungan dari suami. Dengan adanya dukungan suami, istri akan merasa diperhatikan dan dihargai. Dukungan suami berpengaruh besar terhadap istri yang berperan ganda untuk meneruskan karirnya.

Kompleksnya permasalahan yang dihadapi oleh wanita karier karena banyaknya tuntutan pada dirinya sehingga motivasinya dalam bekerja dapat mempengaruhinya dalam menghadapi konflik peran ganda, disamping itu peran ganda yang dijalaninya dapat berpengaruh terhadap kepuasan perkawinannya. Disinilah dukungan suami sangat diperlukan dalam mengurangi konflik peranganda wanita karier. Bahkan dukungan suami dapat pula mempengaruhi kepuasan perkawinan. Wanita memang selalu unik untuk dikaji dan diteliti, penelitian ini akan membuktikan analogi dari beberapa korelasi variabel di atas.

\section{METODE PENELITIAN}

\section{Variabel dan Disain Penelitian}

Penelitian ini menggunakan pendekatan kuantitatif dengan variabel dan disain sebagai berikut:

\section{Gambar 1}

\section{Desain Penelitian}

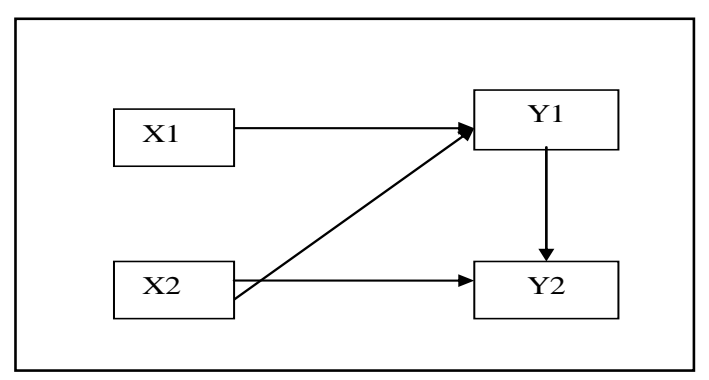

Keterangan:

Variabel Bebas (X1): Motivasi kerja

Variabel bebas (X2) : Dukungan suami

Variabel terikat (Y1): Stres Konflik peran ganda

Variabel Terikat (Y2): Kepuasan perkawinan

\section{Definisi Operasional Variabel}

Motivasi kerja (variabel X1) adalah faktor-faktor yang merangsang dan menimbulkan dorongan atau gairah untuk bekerja pada karyawan, baik secara intrinsik (adanya keinginan untuk meningkatkan prestasi kerja, menghindari kegagalan, bekerja keras dan aktualisasi diri) maupun secara ekstrinsik (imbalan, pujian, hukuman, aturan dan tanggung jawab) berdasarkan tugas yang menjadi tanggung jawab seorang karyawan. Dalam hal ini motivasi kerja diukur dengan menggunakan skala motivasi kerja.

Dukungan Sosial Suami (variabel X2) adalah bantuan berupa tindakan yang bersifat membantu dengan melibatkan emosi, informasi, instrumental, penghargaan dan motivasi yang diberikan pada istri sehingga beban yang dirasakan dapat berkurang dan istri akan merasa dicintai, diperhatikan dan dihargai.

Stres Konflik peran ganda (variabel Y1) adalah suatu kondisi yang tidak menyenangkan dimana terjadi pertentangan dalam diri wanita karir terhadap peran yang diembannya, baik perannya dalam keluarga/rumah tangga maupun perannya ditempat dia bekerja. Skala stres diukur dengan menggunakan gejala-gejala fisik, psikologis dan perilaku.

Kepuasan perkawinan (variabel Y2) adalah terpenuhinya kebutuhan yang bersifat subyektif dalam kehidupan perkawinan yang dirasakan oleh istri terhadap suami /anak-anak. Adapun aspek-aspek yang digunakan adalah keterbukaan, kepercayaan, kebersamaan, toleransi, pernyataan cinta dan afeksi, harapan terhadap perkawinan dan kesadaran terhadap perkawinan.

\section{Subyek Penelitian}

Subyek penelitian ini adalah karyawati karyawati yang bekerja di Bank BNI cabang Makassar. Alasan dipilihnya populasi tersebut karena sesuai dengan tema yang diangkat dan jumlah populasinya cukup besar. Selain itu, profesi tersebut memiliki tuntutan kerja yang cukup tinggi dan jam kerjanya kurang lebih 8 jam/hari. 
Teknik sampel yang digunakan dalam penelitian ini adalah teknik purposive sampling. Teknik purposive sampling adalah salah satu teknik pengambilan sampel Non-Probabilistik yang dilakukan berdasarkan kriteria yang disesuaikan dengan tujuan penelitian atau pertimbangan tertentu dari peneliti. Kriteria yang dimaksud adalah sebagai berikut: (1) Wanita yang sudah menikah, (2) Memiliki anak minimal 1 dengan usia maksimal 5 tahun, (3) Bekerja selama kurang lebih delapan jam sehari, Bekerja minimal lima hari dalam seminggu dan (4) Maksimal 5 tahun sudah bekerja.

\section{Teknik Pengumpulan Data}

Teknik pengumpulan data yang digunakan dalam penelitian ini adalah mempergunakan skala. Ada 4 skala yang digunakan, sesuai dengan jumlah variabel. Cara menjawabnya dengan menggunakan empat alternatif jawaban yaitu SS (Sangat Sesuai), S (Sesuai), TS (Tidak Sesuai), dan STS (Sangat Tidak Se-suai). Pemberian skor dilakukan dengan meli-hat sifat butir. Pemberiaan skor bergerak dari 4 (SS) sampai dengan1 (STS) untuk butir Favo-rable, sedangkan pemberian skor bergerak dari 1 (SS) sampai dengan 4 (STS) untuk butir yang Unfavorable. Skala ini dibuat oleh peneliti.

\section{Teknik Analisis Data}

Teknik analisis data yang digunakan dalam penelitian ini adalah teknik analisis regresi. Semua proses analisis menggunakan Program SPSS For Windows versi 14.

\section{HASIL PENELITIAN DAN PEMBAHASAN}

\section{Hasil Analisa Deskriptif}

Analisa deskriptif digunakan untuk mendiskripsikan kecenderungan variabel-variabel penelitian.

\section{Deskripsi data motivasi kerja}

Tabel 1.

Distribusi Frekuensi Skala Motivasi Kerja

\begin{tabular}{cccc}
\hline $\begin{array}{c}\text { Interval } \\
\text { Skor }\end{array}$ & Frekuensi & $\begin{array}{c}\text { Persentase } \\
(\mathbf{\%})\end{array}$ & Kategori \\
\hline$<97,5$ & 0 & 0 & Rendah \\
$97,5-104$ & 1 & 2,565 & Sedang \\
$104<$ & 29 & 97,435 & Tinggi \\
\hline Jumlah & $\mathbf{3 0}$ & $\mathbf{1 0 0}$ & - \\
\hline
\end{tabular}

Tabel tersebut menunjukkan bahwa motivasi kerja pada wanita karir di kota Makassar berada pada kategori tinggi.

\section{Deskripsi data dukungan suami}

Tabel 2.

Distribusi Frekuensi Skala Dukungan Suami

\begin{tabular}{cccc}
\hline $\begin{array}{c}\text { Interval } \\
\text { Skor }\end{array}$ & Frekuensi & $\begin{array}{c}\text { Persentase } \\
(\boldsymbol{\%})\end{array}$ & Kategori \\
\hline$<86,33$ & 0 & 0 & Rendah \\
$86,33-98,67$ & 6 & 20 & Sedang \\
$104<$ & 24 & 80 & Tinggi \\
\hline Jumlah & $\mathbf{3 0}$ & $\mathbf{1 0 0}$ & - \\
\hline
\end{tabular}

Tabel tersebut menunjukkan bahwa dukungan suami pada wanita karir di kota Makassar berada pada kategori tinggi.

\section{Deskripsi data konflik peran ganda}

Tabel 3.

Distribusi Frekuensi Skala Konflik Peran Ganda

\begin{tabular}{cccc}
\hline $\begin{array}{c}\text { Interval } \\
\text { Skor }\end{array}$ & Frekuensi & $\begin{array}{c}\text { Persentase } \\
(\mathbf{\%})\end{array}$ & Kategori \\
\hline$<53,667$ & 21 & 70 & Rendah \\
$53,67-61,33$ & 7 & 23,3 & Sedang \\
$61,33<$ & 2 & 6,7 & Tinggi \\
\hline Jumlah & $\mathbf{3 0}$ & $\mathbf{1 0 0}$ & - \\
\hline
\end{tabular}

Tabel tersebut menunjukkan bahwa konflik peran ganda pada wanita karir di kota Makassar berada pada kategori rendah.

\section{Deskripsi data kepuasan perkawinan}

Tabel 4.

Distribusi Frekuensi Skala Kepuasan Perkawinan

\begin{tabular}{cccc}
\hline $\begin{array}{c}\text { Interval } \\
\text { Skor }\end{array}$ & Frekuensi & $\begin{array}{c}\text { Persentase } \\
(\boldsymbol{\%})\end{array}$ & Kategori \\
\hline$<93,33$ & 0 & 0 & Rendah \\
$93,33-107$ & 2 & 6,7 & Sedang \\
$107<$ & 28 & 93,3 & Tinggi \\
\hline Jumlah & $\mathbf{3 0}$ & $\mathbf{1 0 0}$ & - \\
\hline
\end{tabular}

Tabel tersebut menunjukkan bahwa kepuasan perkawinan pada wanita karir di kota Makassar berada pada kategori tinggi. 


\section{Hasil Analisis Inferensial}

\section{Pengaruh Motivasi Kerja Terhadap Konflik Peran Ganda}

Hipotesis pertama dalam penelitian ini adalah ada pengaruh motivasi kerja terhadap konflik peran ganda pada wanita karier. Hasil analisa data menunjukkan nilai signifikansi (p) sebesar 0,016 $(\mathrm{p}<0,05)$ berarti pengaruhnya signifikan. Disamping itu, terlihat bahwa ada hubungan negatif antara motivasi kerja dengan stres konflik peran ganda. Artinya bahwa semakin tinggi motivasi kerja maka semakin rendah stres konflik peran ganda. Demikian juga sebaliknya. Hasil analisis menunjukkan adanya pengaruh antara motivasi kerja terhadap konflik peran ganda, yakni dilihat dari nilai koefisien korelasi sebesar $r=0,436$ dan nilai $\mathrm{R}^{2}=0,190$. Hal ini menunjukkan bahwa sumbangan motivasi kerja terhadap konflik peran ganda adalah sebesar $19 \%$.

Motivasi kerja adalah sesuatu yang menimbulkan dorongan atau semangat kerja (Samsuddin, 2005). Motivasi kerja adalah sesuatu yang menimbulkan semangat atau dorongan kerja (Anoraga, 2001). Motivasi kerja adalah salah satu faktor yang mempengaruhi tingkah laku manusia dalam bekerja. Hal tersebut dapat terjadi karena manusia memiliki motif yang segera harus dipuaskan dan mendorong manusia untuk berbuat atau bekerja sehingga akan turut menentukan produktivitas kerja. Izzaty (1997) menyatakan bahwa motivasi kerja adalah keinginan untuk memiliki hasil kerja yang baik sesuai dengan pengharapan.

Dari uraian di atas, maka dapat disimpulkan bahwa motivasi kerja adalah faktorfaktor yang merangsang dan menimbulkan dorongan atau gairah untuk bekerja pada karyawan, baik secara intrinsik (adanya keinginan untuk meningkatkan prestasi kerja, menghindari kegagalan, bekerja keras dan aktualisasi diri) maupun secara ekstrinsik seperti: imbalan (finansial), pujian, hukuman, aturan dan tanggung jawab) berdasarkan tugas yang menjadi tanggung jawab seorang karyawan. Dalam hal ini motivasi kerja diukur dengan menggunakan skala motivasi kerja.

Skala motivasi kerja yang mengacu pada dimensi motivasi dikemukakan oleh Hicks dan Gullet (Prabandari, 2003) terdiri atas dimensi internal dan external. Motivasi internal adalah kebutuhan, keinginan atau harapan yang terha- dap dalam pribadi seseorang yang menentukan berbagai pandangan, yang akan memimpin tingkah laku dalam situasi yang khusus. Motivasi eksternal meliputi kekuatan yang ada di luar diri individu seperti halnya faktor pengendalian oleh manajer, juga meliputi hal-hal yang berkaitan dengan gaji/upah, kondisi kerja, kebijaksanaan organisasi dan pekerjaan yang mengandung hal-hal seperti pengembangan, penghargaan dan tanggung jawab.

\section{Pengaruh Dukungan Suami Terhadap Stres Konflik Peran Ganda}

Hipotesis kedua dalam penelitian ini adalah ada pengaruh dukungan suami terhadap stres konflik peran ganda pada wanita karier. Hasil analisa data menunjukkan nilai signifikansi (p) sebesar 0,00 ( $p<0,05)$, artinya pengaruhnya signifikan. Disamping itu terlihat bahwa ada hubungan positif antara dukungan suami dengan stres konflik peran ganda. Artinya bahwa semakin tinggi dukungan suami maka semakin rendah stres konflik peran ganda. Hasil analisis menunjukkan adanya pengaruh antara motivasi kerja terhadap konflik peran ganda, yakni dilihat dari nilai koefisien korelasi sebesar $r=0,745$ dan nilai $R^{2}=0,556$. Hal ini menunjukkan bahwa sumbangan motivasi kerja terhadap konflik peran ganda adalah sebesar 55,6\%.

Adam (Kumolohadi, 2001:33) mengemukakan bahwa dukungan sosial dari suami adalah bantuan yang diberikan oleh suami. Beberapa ahli juga berpendapat bahwa dukungan sosial suami adalah dukungan atau bantuan dalam memberikan dorongan atau motivasi tersendiri pada istri yang berperan ganda yang biasanya ditunjukkan dalam bentuk perhatian, kesediaan mendengarkan keluh kesah dan setiap saat memberikan masukan-masukan yang sifatnya positif. Dengan demikian, beban istri menjadi berkurang dalam menghadapi konflik peran ganda dan kepuasan perkawinan pun akan meningkat karena adanya kebersamaan, pengertian dan toleransi.

Aspek-aspek Dukungan Sosial Suami disusun oleh peneliti berdasarkan aspek-aspek yang dikemukakan oleh Sarafino (Suryadi, 2003) dan Fenlanson dan Beehr (Farhati \& Rosyid, 2002: 5) yang meliputi (1) dukungan emosional yaitu berupa dukungan yang melibatkan ekspresi rasa empati dan perhatian terhadap individu, sehingga individu tersebut 
merasa nyaman, dicintai dan diperhatikan. Dukungan ini melibatkan perilaku seperti memberikan perhatian dan afeksi serta bersedia mendengarkan keluh kesah; (2) dukungan informasi yaitu berupa saran, pengarahan dan umpan balik tentang bagaimana cara penyelesaian masalah; (3) dukungan instrumental berupa bantuan secara langsung berupa bantuan finansial atau bantuan dalam melakukan tugas-tugas tertentu; (4) dukungan penghargaan yaitu dukungan yang melibatkan ekspresi pernyataan setuju dan penilaian positif terhadap ide-ide, perasaan dan performa orang lain; dan (5) dukungan motivasi yaitu berupa pemberian dorongan dan semangat pada individu yang membutuhkan untuk menyelesaikan permasalahan yang dihadapi.

\section{Pengaruh Dukungan Suami terhadap Kepuasan Perkawinan}

Hipotesis ketiga dalam penelitian ini adalah ada pengaruh dukungan suami terhadap kepuasan perkawinan pada wanita karier. Hasil analisa data menunjukkan nilai signifikansi (p) sebesar $0,00 \quad(\mathrm{p}<0,05)$, artinya pengaruhnya signifikan. Disamping itu, terlihat bahwa ada hubungan positif antara dukungan suami dengan kepuasan perkawinan. Artinya bahwa semakin tinggi dukungan suami maka semakin tinggi kepuasan perkawinan. Hasil analisis menunjukkan adanya pengaruh antara dukungan suami dengan kepuasan perkawinan, yakni dilihat dari nilai koefisien korelasi sebesar $r=0,645$ dan nilai $\mathbf{R}^{2}=0,416$. Hal ini menunjukkan bahwa sumbangan dukungan suami terhadap kepuasan perkawinan adalah sebesar 41,6\%.

Dukungan suami sangat mempengaruhi kepuasan dalam perkawinan terutama pada wanita karier. Walgito (Tenriawaru, 2005) menyatakan bahwa pagar tercapai kepuasan perkawinan maka pasangan suami istri perlu saling mengerti apa yang dibutuhkan pasangannya. Disamping itu, juga harus memiliki sikap saling dapat menerima dan memberikan cinta kasih, yaitu dapat mengungkapkan dan mengekspresikan rasa cintanya dalam bentuk yang nyata, sepert perhatian, pernyataan cinta dan sentuhan. Ini merupakan wujud dari dukungan sosial yang pada pasangan. Senada dengan pendapat yang dikemukakan oleh Tenriawaru (2005) di atas, bahwa faktor yang mempengaruhi kepuasan pernikahan yang cukup dominan adalah faktor psikologis, yakni kemampuan seseorang dalam memahami pasangan dan memberikan dukungan sosial terhadap apa yang dilakukan oleh pasangan.

\section{Pengaruh Stres Peran Ganda terhadap Kepuasan Perkawinan}

Hipotesis keempat dalam penelitian ini adalah ada pengaruh stres konflik peran ganda terhadap kepuasan perkawinan. Hasil analisa data menunjukkan nilai signifikansi (p) sebesar $0,009(\mathrm{p}<0,01)$, artinya pengaruhnya sangat signifikan. Disamping itu, terlihat bahwa ada hubungan negative antara stres konflik peran ganda dengan kepuasan perkawinan. Artinya bahwa semakin tinggi stres konflik peran ganda maka semakin rendah kepuasan perkawinan. Hasil analisis menunjukkan adanya pengaruh antara stress peran ganda dengan kepuasan perkawinan, yakni dilihat dari nilai koefisien korelasi sebesar $r=0,429$ dan nilai $R^{2}=0,184$. Hal ini menunjukkan bahwa sumbangan stress konflik peran ganda terhadap kepuasan perkawinan adalah sebesar 18,4\%.

Achir (Marlinda, 2006) mendefinisikan konflik peran ganda adalah keinginan atau ambisi yang menimbulkan rasa bersalah bahwa ia belum puas dengan fungsinya sebagai istri, sebagai ibu dan pengelola rumah tangga. Khan (Hamid, 2005) mengemukakan bahwa konflik peran ganda dalam kaitannya dengan peran seseorang wanita sebagai wanita karir dan ibu rumah tangga adalah bentuk dari inter-roleconflict dimana tekanan peran dari pekerjaan dan lingkungan keluarga satu sama lain saling bertentangan. Konflik ini terjadi karena partisipasi pada perannya dalam pekerjaan dirasakan sulit akibat partisipasinya pada perannya dalam rumah tangga, demikian pula sebaliknya.

Menurut Anoraga (1998: 107) segala macam bentuk stress pada dasarnya disebabkan oleh kurang mengerti akan keterbatasannya sendiri. Ketidakmampuan untuk melawan keterbatasan inilah yang akan menimbulkan frustasi, konflik, gelisah, dan rasa bersalah yang merupakan tipe-tipe dasar stress.

Menurut Rini (2002) gejala-gejala stres terbagi atas tiga, yaitu: (1) Reaksi psikologis: merasa tertekan, merasa tegang dan tidak rileks, merasa lelah secara mental, terus merasa takut dan khawatir, meningkatnya kejengkelan dan keluhan, merasa adanya konflik, frustasi dan ingin marah, gelisah, tidak dapat berkonsentrasi atau menyelesaikan masalah dengan cepat, 
sering menangis, menjadi lebih rewel, muram, sulit mengambil keputusan, keinginan untuk lari dan bersembunyi, takut dipermalukan atau gagal, berkurang kemampuan untuk merasakan senang atau gembira, (2) Reaksi fisik: otot-otot tegang, jantung berdebar-debar lebih cepat, atau tidak teratur, pernafasan lebih cepat dan pendek, berkeringat, kewaspasdaan yang berlebihan, perubahan nafsu makan, otot melemah atau bergetar, gugup, tangan dan kaki lemas, lelah dan lemas, resah dam gelisah terus, sakit punggung dan (3) Reaksi perilaku: pikiran sering berubah-ubah, mudah menangis, suka mengeluh, kesulitan untuk berkata tidak, sering mengharap orang lain dapat memahami mereka sepenuhnya, terjadi perubahan dalam kebiasaan seksual (kehilangan minat, meningkatnya kebutuhan seks daripada biasanya, perubahan dalam sikap), sifat yang lemah lembut bisa berubah menjadi galak dan agresif.

Hawkins (Soetomo, 1999) mendefinisikan kepuasan perkawinan sebagai kebahagiaan, kepuasan dan pengalaman menyenangkan yang bersifat subyektif yang dirasakan oleh pasangan suami istri dari keseluruhan aspekaspek perkawinannya. Sedangkan McElwain \& Korabik (2005) kepuasan perkawinan adalah persepsi terpenuhinya kebutuhan dan harapan suami atau istri yang dilihat dari sikap positif atau negatif suami istri terhadap kehidupan perkawinannya.

Aspek-aspek kepuasan pernikahan, menurut McElwain \& Korabik (2005) adalah sebagai berikut (1) Keterbukaaan, Suami dan istri harus berani membuka diri, menyatakan pendapat, pikiran dan perasaannya. Hal ini penting agar keduanya dapat lebih saling mengenal dan memahami pribadi masing-masing, (2) Kepercayaan, suami dan istri harus saling mempercayai, kepercayaan ini merupakan dasar perkembangan suami istri, tanpa adanya kepercayaan dalam kehidupan perkawinan, suami istri tidak akan merasakan ketentraman, selalu saling curiga dan cemburu, (3) Kebersamaan, pasangan suami istri mempunyai waktu untuk berkumpul atau berekreasi bersama, yang dapat digunakan untuk berbincang-bincang atau membicarakan masalah penting dalam kehidupan keluarga, (4) Toleransi, sikap toleransi diantara suami istri, merupakan sikap saling menerima dan memberi, serta sikap saling menolong, sikap ini akan menumbuhkan penghargaan dan rasa hormat terhadap kepribadian, prestasi, minat dan individualitas pasa- ngannya, (5) Pengertian, Pasangan suami istri saling memahami motif-motif tingkah laku pasangannya, sebab-sebab mengapa ia berbuat demikian dan mempunyai pengartian terhadap latar belakang kehidupan masing-masing. Pasangan suami istri perlu saling mengerti apa yang dibutuhkan pasangannya, (6) Pernyataan cinta dan afeksi, pasangan suami istri juga harus memiliki sikap saling dapat menerima dan memberikan cinta kasih, yaitu dapat mengungkapkan dan mengekspresikan rasa cintanya dalam bentuk yang nyata, sepert perhatian, pernyataan cinta dan sentuhan, (7) Harapan terhadap perkawinan, pasangan suami istri merasa optimis bahwa perkawinannya dapat berlangsung sampai akhir hayat, baik suami maupun istri mempunyai keyakinan mereka akan tetap saling setia dan mencintai dalam keadaan apapun dan (8) Kesadaran terhadap peranan perkawinan, adanya kesadaran pasangan suami istri akan pentingnya pernikahan bagi diri mereka untuk dapat berkembang menjadi pribadi yang sehat baik jasmani maupun rohani.

Penelitian Strong dan Give (Rahmah, 2005) menemukan bahwa bila istri memutuskan untuk bekerja di luar rumah berarti mereka akan mengurangi kualitas perannya dalam perkawinan dan mengurangi waktunya untuk bersama dengan pasangan dan angota keluarga yang lain yang pada akhirnya akan berpengaruh terhadap kualitas perkawinannya.

\section{PENUTUP}

Berdasarkan hasil temuan dalam penelitian ini maka dapat disimpulkan: Ada pengaruh negatif motivasi kerja terhadap stres konflik peran ganda, artinya semakin tinggi motivasi kerja maka semakin rendah stres konflik peran ganda, dan sebaliknya. Selain itu Ada pengaruh negatif dukungan suami terhadap stres konflik peran ganda, artinya semakin tinggi dukungan suami maka semakin rendah stres konflik peran ganda.

Selanjutnya ada pengaruh positif dukungan suami terhadap Kepuasan perkawinan, artinya semakin tinggi dukungan suami maka semakin tinggi kepuasan perkawinan, dan sebaliknya. Ada Pengaruh negatif antara stres konflik peran ganda dengan kepuasan perkawinan, artinya semakin tinggi stres konflik peran ganda maka semakin rendah kepuasan perkawinan. 


\section{DAFTAR PUSTAKA}

Anoraga, P. 2005. Psikologi Kerja. Jakarta: PT Rineka Cipta.

As'ad. 2003. Psikologi Industri.Yogyakarta: Liberty.

Astrini. 2005. Wanita sehat, keluarga bahagia. Stres pada wanita (online), (http:// www.geocities.com, diakses 11 April 2005)

Azwar, S. 1999. Penyusunan Skala Psikologis. Yogyakarta: Pustaka Pelajar.

Brown, R. 1965. Social Psychology. Collier MacMillan International Editions

Cosmopolitan. 2001. Women Career Handbook. Jakarta: PT Enka Parahiyangan.

Cooper \& Straw. 1995. Stress Management yang sukses dalam sepekan. Terjemahan Adullah. Jakarta: Megapoin.

Farhati, F \& Rosyid.H.F. 1996. Karakteristik Pekerjaan, Dukungan sosial dan tingkat Burnout pada Human Service Corporation. Jurnal Psikologi,I,1-12

Hadi, S. 1992. Statistik 2. Yogyakarta: Fakultas Psikologi Universitas Gajah Mada.

Hadi, S. 2004. Metodologi Research. $\left(2^{\text {th }}\right.$ ed). Yogyakarta:Andi Offset.

Hamid, Harlina.2005. Hubungan Antara Androginitas Dengan Konflik Peran Ganda Pada Wanita. Jurnal Intelektual. Vol 3. No.2. Makassar: UNM.

Himam, F \& Putri, A.U. 2005. Ibu dan Karir: Kajian Fenomenologi Terhadap DualCareer Family. Jurnal Psikologi.Vol:32. No.1.Yogyakarta. Fakultas Psikologi Universitas Gadjah Mada.

Ignatia.2003. Konflik-Konflik Pada Ibu Bekerja Di Luar Rumah http://www. psikologi-untar.com, diakses tanggal 8 Januari.2001

Izzaty, E.R. 1997. Konflik-konflik pada ibu bekerja diluar rumah http://www. google.com diakses 13 April 2004.

Juniarly, A. 2001. Tingkat Depresi Ibu Rumah Tangga dan Berperan Ganda di Kompleks Perumahan Waihitam Palembang, Skripsi (tidak diterbitkan). Yogyakarta: Fakultas Psikologi Universitas Islam Indonesia.

Kartini Kartono.2004. Psikologi Sosial Untuk Manajemen, Perusahaan dan Industri. Jakarta: PT Raja Grafindo Persada.
Kumolohadi,R.2001. Tingkat Stres Dosen Perempuan UI Ditinjau dari Dukungan Suami. Jurnal Psikologi, No.12 (29-42).

Lindgren,C.H.1973. An Introduction to Social Psychology. New Delhi: Willey Eastern Private Limited.

Marlinda,P.2006. Hubungan Konflik Peran Ganda Wanita Bekerja Dengan Kepuasan Perkawaninan Di Balai Besar Penga-wasan Obat Dan Makanan Makassar, Skripsi (tidak diterbitkan). Makassar: Fakultas Psikologi Universitas Indonesia Timur.

McElwain.A.K \& Korabik.K.2005. WorkFamily Guilt, A Sloan Work and Family Encyclopedia Entry http://www.findarticles.com,diakses 16 Desember 2006

Munandar, A,S. 2001. Psikologi Industri dan Organisasi. Jakarta: UI-Press.

Natsir, R. 2005. Hubungan Antara Penerimaan Diri dan Toleransi Stres pada Karyawati BNI Sudirman Makassar, Ringkasan Skripsi (tidak diterbitkan). Makassar: Fakultas Psikologi: Universitas Negeri Makassar.

Nawai, H. 2001. Motode penelitian bidang sosial (9 th ed) Yogyakarta. Gadjah Mada University Press.

Prabandari, R. 2003. Hubungan Antara Konsep Diri dan Motivasi Bekerja Pada Wanita Karir, Ringkasan Skripsi (tidak diterbitkan). Yogyakarta: Fakultas Psikologi Universitas Gadjah Mada.

Rahmah, W. 2005.Hubungan Antara Self Efficacy dan Dukungan Suami Dengan Tingkat Kecemasan Terhadap Peran Ganda Pada Ibu Yang Bekerja Fulltime. Ringkasan Skripsi (Tidak Diterbitkan). Surabaya: Fakultas Psikologi Universitas Airlangga.

Rini, J, F. 2002. Wanita Bekerja http://www.epsikologi.com, diakses Desember 2006 .2002. Stress Kerja http://www.epsikologi.com, diakses Desember 2006.

Samsuddin, Sadili. 2005. Manajemen Sumberdaya Manusia. Bandung: CV. Pustaka Setia.

Setyowati, R \& Riyono, B. 2003. Perbedaan Aspirasi Karir Antara Wanita Yang Sudah Menikah dan Yang belum Menikah Pada Pegawai Negeri Sipil. Psikologika: Jurnal Pemikiran dan Penelitian Psikologika. No:16 Tahun: VII. 
Sianturi, Roslinda. 2006. Polwan Sebagai Pelayan Masyarakat dan Tanggung Jawab Dalam Keluarga http://www. waspada-online.co.id, diakses Desember 2006

Shaevitz, M,H. 1993. Wanita Super (Terjemahan).Yogyakarta: Kanisius.

Soetomo, E. S. 1999. Kajian Tentang Pengaruh Konflik Peran Dan Keterampilan Manajemen Terhadap Persepsi Tentang kinerja Pada Wanita Manajer http://www.litbang.co.id, diakses 13 Desember 2006

Steers, R. M \& Porter, L. W. 1987. Motivation and Work Behavior. USA: Mc Graw Hill Book Company.

Sundari, S.H.S. 2005. Kesehatan Mental dalam Kehidupan. Jakarta: Rineka Cipta.

Suryadi, E. 2003. Gambaran Konflik dan Reaksi Emosional Perempuan Dalam Menentukan Prioritas Peran Gandanya http://.www.psikologi-untar.com,diakses tanggal 8 Januari 2007

Tanpa Nama. 2004. Wanita Berperan Ganda http://www.waspada.co.id.2004, diakses 9 Desember 2006

Tanpa nama. 2003. Kelemahan Wanita Yang Harus diubah. www.kompas.com diakses 9 Desember 2006

Tenriawaru, A. 2005. Pengaruh Dukungan sosial terhadap stres pada wanita berperan ganda di PT Telkom Makassar. Skripsi (tidak diterbitkan). Makassar. Fakultas Psikologi Universitas negeri Makassar.

Triwahyuningsih, E. 2004. Sukses "Peran Ganda" Wanita Tunanetra (online). (http://www.mitranetra.or.id, diakses 13 Desember 2006

Winarsunu, T. 2006. Statistik Dalam Penelitian Psikologi dan Pendidikan. Malang: UMM 